\title{
La voz de los creadores: entrevista a Claudia Masin ${ }^{1}$
}

\section{INTRODUCCIÓN: CUANDO LA POESÍA DIALOGA CON EL CINE}

Claudia Masin (Resistencia, Chaco, Argentina, 1972) sitúa la pantalla frente al papel en blanco y consigue que ambos dialoguen entre sí. Masin es psicoanalista, escritora, coordinadora de talleres literarios y docente de la carrera Artes de la Escritura en la Universidad Nacional de las Artes de Argentina. Su obra ha conocido multitud de países, puesto que ha sido traducida al inglés, francés, portugués o italiano; además, ha participado en festivales de poesía en Argentina, Uruguay, Chile y Estados Unidos. Recientemente, su antología La materia sensible (2020) se ha editado en España. Su extensa producción, que cuenta con nueve libros de poesía y dos antologías, posee un gran peso del sector audiovisual. Esta poesía cinéfila - si bien es cierto que también su prosa se nutre de numerosas referencias cinematográficas - se hace patente, especialmente, en sus obras La vista (2002) y Lo intacto (2018).

Palabra e imagen son distintos medios para narrar, para crear, para contar. En la obra de Claudia Masin, ambos medios convergen. Sus poemas, sin embargo, también seconstruyen sobre imágenes que están más allá de las películas a las que hace referencia. Parten del cine, se nutren de él, pero llegan a construir una historia que se teje por encimade cualquier película. Por eso, pese a que la semilla de algunos de algunos textos de $L a$ vista sean París, Texas (Wim Wenders, 1984), Criaturas celestiales (Peter Jackson, 1994), Ana y los lobos (Carlos Saura, 1973), Muerte en Venecia (Luchino Visconti, 1971) o La luna (Bernardo Bertolucci, 1979), cada poema supone una recreación de algo que se ha expuesto en una pantalla. Aunque la primera persona sea la voz que toma las riendas, esta no se encarna en un solo personaje: podemos leer a través de un hombre, una mujer, un niño o un anciano. Por otra parte, si hablamos de Lo intacto, nos encontraremos con un poemario que también se interesa en dialogar con el cine, en aprovechar las posibilidades que ofrece la intertextualidad y el encuentro del medio audiovisual con el literario, con referencias como Her

\footnotetext{
${ }^{1}$ Esta entrevista tuvo lugar de manera telemática (España-Argentina) el día 9 de marzo de 2019.
}

Trasvases entre la literatura y el cine, 3, 2021, págs. 317-324 
(Spike Jonze, 2013), Esteros (Papu Curotto, 2016), Tomboy (Céline Sciamma, 2011) o Cerezos en flor (Doris Dörrie y Hanami, 2008).

En ambas obras, palabra e imagen se complementan y se retroalimentan. Es decir, los textos adquieren aún mayor significado y fuerza narrativa gracias al gran poder visual que en ellos se concentra. El poema nace de una película y, al mismo tiempo, crece convirtiéndose en algo nuevo, algo que trasciende a la propia historia. La vista y Lo intacto pueden leerse aunque se desconozcan las 21 películas del primero o las 28 del segundo - todas ellas, muy diversas en cuanto a procedencia, año de creación y temática - que planean sobre los poemas, porque hay escenas que encontramos en el libro y, sin embargo, no existen en la película a la que hacen referencia. En ambas obras, el amor esun hilo conductor, pero también lo son la violencia, la infancia, la fragilidad, la pérdida o el dolor, al igual que la posibilidad de cura, temáticas universales que podríamos encontrar en cualquier poemario, surjan alrededor del cine o no. Y es que, como la propia autora afirma, el séptimo arte y la literatura nos dan la posibilidad de convertirnos en otra persona, de sentir sobrepasando los límites de nosotros mismos, de nuestra propia mirada. Y quizáses esto lo que hace que los poemarios de Claudia Masin sean distintos a cualquier otro que tenga un referente cinematográfico como cordón umbilical: el poema es capaz de traducir una historia captada por una cámara y contada a través de una pantalla, pero también es capaz de traducir una historia que solo la vista capta y que solo los versos de un poema podrían contar. Claudia Masin traduce el cine, pero también traduce el mundo.

\section{ENTREVISTA A ClaUda MASIN SOBRE LOS VÍNCULOS ENTRE SU POESÍA Y EL CINE}

Kris León: El cine es la matriz de tus libros de poemas La vista y Lo intacto pero, en general, toda tu obra tiene una gran influencia del sector audiovisual. ¿Por qué escribir sobre cine? Y en concreto, ¿por qué escribir poesía sobre cine?

Claudia Masin: El cine es en mi vida una pasión igual o más potente que la literatura. Soy cinéfila del mismo modo en que soy lectora: con la misma voracidad y la misma — digamos - insaciabilidad. Cada libro, cada película hermosa, inquietante, sorprendente o conmovedora, genera inmediatamente en mí el deseo de otro libro, o de otra película. Es decir, mi escritura en general y mi escritura en relación al cine surgen de lugares idénticos: solo escribo acerca de aquello que me apasiona, que no elijo, aquello por lo que soy tomada, arrebatada, sacada de mí. Escribo acerca de aquellas experiencias tan intensas de las que resulta una urgencia, una necesidad, el acto de escribirlas. E incluso, en muchos casos, "exorcizar" o elaborar - para decirlo de forma más psicoanalítica-, eso innominado y profundamente inquietante que las palabras, en el mejor de los casos, cercarán, 
rondarán y rodearán, sin llegar a tocarlo nunca. Es increíble, de todos modos, la operatoria que la escritura realiza sobre eso sin forma ni nombre, o mejor dicho, sobrela posibilidad de cada uno/a de convivir con ello y soportarlo - y me refiero a soportar suintensa belleza o su intenso horror, o ambas cosas, o muchas más-. Podría decir, entonces, que no fue una elección consciente escribir acerca de películas, sino que ver cine $-\mathrm{y}$, particularmente, ciertos films - es para mí una experiencia intensísima, que muchas veces, muchas, modificó mi mundo y mi modo de ver las cosasy por ende, como otras experiencias intensísimas, se convirtió en materia de mi poesía, que, como ya dije, se nutre de lo intenso y lo extraordinario. Lo extraordinario no en el sentido de inusitado o de inusual, sino en el de aquello que produce efectos perdurables en la subjetividad, en la mirada, aquello que, aunque estuviera ahí desde siempre, advertimos por primera vez a partir de que algo o alguien — en este caso, el cine y esas determinadas películas - nos lo señale.

K.L.: Han pasado más de quince años entre la publicación de ambos libros. Es inevitable que haya habido cambios en tu visión del mundo y en tu propia escritura. Por eso, aunque la temática inicial sea la misma, ¿has abordado Lo intacto de manera diferente?

C. M.: Efectivamente. La vista es un libro completamente diferente a Lo intacto, y a los otros dos libros aún inéditos con los que se conforma una trilogía (Lo intacto, El cuerpo y La intensidad). La vista está mucho más ligado a dos tiempos cronológicos, la infancia y la adolescencia, y muchas de las películas que incluye tienen ese sesgo. Podría decirse quees un libro que rastrea, explora y se pregunta sobre el origen de los sentimientos amorosos: lo iniciático, al terreno del amor a la madre, al padre; los primeros amores que conocemos, como terrenos que son necesarios abandonar y que de alguna manera prefiguran o moldean nuestros futuros vínculos; nuestra relación con el amor en general; y a veces, incluso la posibilidad misma de que se configure la capacidad de amar, o bienquede naufragando en un magma confuso que no nos permita ya salir de allí y nos condene. Pienso, por ejemplo, en los amores de La ciénaga (2001), de Lucrecia Martel.

En los siguientes tres libros, escritos quince años después de $L a$ vista, es nuevamente la experiencia amorosa la que está en el centro de la cuestión. La gran mayoría de las películas tienen que ver con el amor. Pero ya no se trata de la experiencia amorosa iniciática-aunque haya algunos poemas como "Esteros" que tienen algún resabio de aquello-, sino del amor que incluye y contiene la posibilidad cierta e inexorable de la pérdida, del desencuentro, del desamor. Es la voz de quien ya sabe que es necesario, aunque inconmensurablemente doloroso, aceptar la pérdida y la incompletud como partedel sentimiento amoroso, que es precisamente un sentimiento que nos da la ilusión de completarnos y que siempre, en algún momento, se revela como 


\section{Cristina León Sánchez}

fallida, imperfecta. Como la escritura misma, podríamos decir. Como ese impulso que nos lleva a escribir, que fracasa cada vez en su intención de decirlo todo, y con ese fracaso extraordinariamente fértil nos relanza a la escritura, al intento, más allá de la conciencia de su precariedad, de la desilusión que necesariamente conlleva. A su vez, en los tres libros escritos entre 2017, 2018 y 2019, hay también una mirada fascinada y "celebratoria" de la experiencia amorosa, como aquello que nos da la máximaoportunidad que conoceremos en la vida y esto para mí una cuestión central- de ser otros, de fusionarnos con otra persona, de ligarnos de tal manera a otra existencia que "nose sepa muy bien dónde comienza, dónde termina cada cuerpo" (cita Claudia de memoriaen alusión a "Persona", uno de los poemas que conforman Lo intacto).

K.L.: A veces necesitamos que pase un tiempo para llegar a ser capaces de contar o escribir sobre un hecho concreto. Quizás, hay películas que nos dejan un poso y sobre las que escribimos a partir de su recuerdo, en lugar de hacerlo justo después de su visionado. En tu caso, ¿cómo se escribe un poema a partir de una película?

C. M.: Hay, en mi experiencia, muchísimas maneras de escribir un poema a partir de una película. En muchos casos he escrito los poemas inmediatamente después de ver el film, pero en ocasiones han pasado cosas muy extrañas, como en relación al poema "La luna", basado en la película homónima de Bertolucci. Yo no había visto siquiera la película completa - por esos años era muy difícil conseguir una copia subtitulada y me es imposible ver una película doblada, me parece una violencia que se ejerce sobre la obra-, y cuando apareció el poema se basó en esa única escena que recordaba, vista en un ciclo de cine muchos años antes de que la idea de escribir sobre películas apareciera. Esta únicaescena me había parecido tan poderosa, tan excepcional, que el poema completo surgió a partir de ella. Lo más curioso es que esa escena no está incluida en el poema, sino aludida muy lateralmente.

K. L.: La carga visual de tus poemas es muy fuerte. Las sensaciones llegan al lector a travésde poderosas imágenes. Se podría decir que leer tu poesía es estar visualizando unapelícula sobre un papel en blanco. ¿Puede nacer un poema a partir de una imagen, o es el poema el que busca las imágenes para poder contarse?

C.M.: Creo que suceden las dos cosas. Una imagen muy poderosa puede bastar, como en el caso del poema "La luna", para generar un poema. Pero a veces el poema va creando sus propias imágenes para dar cuenta del universo que determinada película abrió en mí. Hayimágenes que pueden, o no, tener que ver directa y explícitamente con el imaginario de la propia película. 
K.L.: Y en la sociedad actual, donde la cultura de lo visual es la hegemónica y donde tododebe estar en internet y en redes sociales para llegar a existir, ¿qué pueden aportarlas palabras, la poesía?

C.M.: Creo que estamos viviendo una época en la cual hay una devaluación tremenda de la palabra, donde desde los propios poderes hegemónicos se intenta instalar la idea de que el pensamiento, la sensibilidad y su expresión a través del lenguaje son cuestiones anacrónicas, que apelan a una relación con la temporalidad, porque la inmediatez es la condición para que una experiencia merezca ser vivida. La demora, la dilación, el hiato, la espera que la palabra abre, y que sobre todo el lenguaje poético necesita para existir, va a contramano de ese discurso hegemónico y, por ende, es revulsivo. El lenguaje poético es improductivo por excelencia, en el sentido de que apunta siempre a un plus, a un gasto, a un exceso, lo cual en nuestra economía emocional capitalista es una herejía: no solo no produce desde el punto de vista mercantil, desde el punto de vista del intercambio de los bienes, sino que genera pérdida, genera gasto. Es una agitación sin sentido y sin destino, desde el punto de vista de la lógica capitalista adulta, blanca, heterosexual, patriarcal, de clase media. Esta lógica se contrapone notablemente a la lógica que impera en el lenguaje poético, que surge, que se entronca con el habla infantil,el habla de las mujeres, de las minorías, de los marginados de toda laya.

K.L.: ¿Qué tiene que tener una película para que te impulse a escribir sobre ella, o a partirde ella?

C.M.: Intensidad. Una relación con la verdad que esté dada por eso: por el impacto emocional que carga y que transmite. La mera pericia técnica, la habilidad a la hora de contar una historia, la belleza o lo estético de un film pueden seducirme a la hora de ver una película desde el lugar de espectadora, pero no me producen el deseo de escribir acerca de ella.

K.L.: A diferencia de otros libros de poemas con temática cinematográfica, tus libros pueden leerse sin que se hayan visto las películas sobre las que se gestan, porque noson poemas de homenaje a actrices, directores o a películas, donde la referencia es directa y evidente. Además, en alguna ocasión has afirmado que en tus libros aparecen imágenes que no existen en la película a la que aluden. ¿Escribes partiendo de una película, pero contando algo que va más allá de esa historia?

C.M.: Absolutamente. No son poemas que "homenajean" al cine, actores, directores, etc. Son poemas que parten del efecto, del impacto, de la conmoción que una película ha generado en mí. Por eso, muchas veces no hay referencias rastreables de la película en el poema, aunque 


\section{Cristina León Sánchez}

invariablemente se puede encontrar una relación que está ligada más bien al espíritu de la película, a su clima, a sus subtextos, no a su narrativa lineal ni a su imaginario explícito. Los poemas recrean la película yendo más allá de ella, no son meroscomentarios o resúmenes en verso, sino que construyen otro mundo, pero un mundo que no podría haber existido sin el disparador de esa película en particular. Cada una de las películas sobre las que escribí es una obra que se ligó de alguna manera con zonas de misubjetividad que quizás de otro modo no hubieran podido encontrar una expresión.

K.L.: En alusión a la cuestión anterior, llama la atención el hecho de que, pese a que hablemos de poemas sobre cine, la sensación de unidad es muy clara, y no se percibe una acumulación de textos que simplemente quieran homenajear al medio cinematográfico. ¿Planteaste escribir cada uno de ellos con una temática concreta oun hilo conductor definido?

C.M.: Es cierto que hay una unidad en cada uno de los libros, pero no fue buscada. No sabía, por ejemplo, cuando estaba escribiendo $L a$ vista, que gran parte de los poemas iban a tener que ver con la infancia, con la educación sentimental, con lo iniciático. Fue una sorpresa para mí cuando leí los textos en su versión final y me encontré con ese hilo conductor que había estado siempre allí pero que yo no había visto. Como dice Bellessi en relación a los "programas" que una se plantea cuando empieza a escribir un libro de poemas: "el poema es el accidente en el programa”, es decir, aquello intempestivo, inesperado, sorpresivo, que escapa al control y que muchas veces imprime una direcciónal libro que no es en absoluto la que habíamos pensado para él. Por suerte.

K.L.: Se suele decir que es imposible que no haya algo de una misma en aquello que se escribe. Quizás, usar la voz de diversos personajes cinematográficos otorga más libertad para poder hablar sobre ciertas partes de nosotros, o sobre ciertos temas que nos conmueven. ¿Hay algo de eso en tus poemas?

C.M.: Cada una de estas películas me ofreció lo que podríamos llamar una máscara, una identidad alternativa desde la cual escribir. Un hermoso ejercicio de alteridad que a la vez que me empujó a salirme de mí misma para hablar con la voz de otro, de otra, me llevó a encontrar en mi propia subjetividad aquello que me hacía sorprendentemente parecida a aquel, a aquella de quien adoptaba la voz. No somos tan diversos, no estamostan separados. El ejercicio de adoptar la voz de otra persona es sanador: no hay nada másalienante y enfermizo que habitar un solo cuerpo, una sola vida, una sola idea del mundo. 
K.L.: ¿Qué le aporta el cine a tu vida y a tu escritura, especialmente, a tu poesía?

C.M.: Mi historia personal en relación al cine tiene, creo, una gran incidencia en el hecho de que haya pasado a formar parte de un modo tan "nodal" de mi vida y mi escritura. Yo nací en una ciudad muy pequeña, Resistencia, en la que viví hasta los diecisiete años y ala que sigo volviendo asiduamente. En esos años, plena década de los ochenta, es decir, antes del surgimiento de internet, de las redes sociales, del acceso fácil y rápido a las imágenes y a la información acerca de otros lugares, de otras costumbres y de otras historias diferentes a la propia, no había en mi ciudad muchas posibilidades de acceder al mundo que se extendía más allá de la reducida experiencia personal, salvo a través de los libros y las películas. Y cada vez que podía, leía, veía films. Yo estoy convencida de que el arte en general, y la literatura y el cine en particular, permiten desarrollar una capacidad que es para mí valiosísima, rara y hermosa: la de la empatía. La de poder ponerse en el lugar de otro, otra, la de poder sentir cómo sería ser ese otro, esa otra. Un niño, una niña, un hombre, una mujer trans, un anciano; o cómo sería ser un animal, una planta, una piedra. La literatura y el cine nos muestran la vida de los otros seres, y a partirde esa inmersión en la vida de los demás, nos permiten ejercitar una herramienta necesaria para desarrollar la empatía: la imaginación. Tiendo a pensar que el odio, el miedo al otro, a la diferencia, no es -en la mayoría de los casos- más que falta de imaginación. No maldad, sino falta de imaginación. Incapacidad de pensarse como otro, como otra, ignorancia. Es decir, el tipo de ignorancia que nos puede llevar a pensar que somos algo concreto, irreductible, compacto, inmutable, que hay un yo que no muta, una identidad monolítica. Que no somos afectados, contagiados, tocados, conmocionados, conmovidos e incluso arrasados a veces por los otros, por lo otro. El arte, desde mi modo de ver, nosotorga, en el mejor de los casos, esa conciencia de no separatividad en relación a lo que nos rodea, o al menos la posibilidad de adquirirla. La literatura y el cine en particular relatan historias, muchas de ellas ligadas a paisajes, subjetividades, realidades absolutamente ajenas al pequeño $-\mathrm{y}$ a veces mezquino y solipsista- mundo en que se mueve cada uno/a. Ver una película, leer un libro, filmar una película, escribir un poemason, creo, modos de ejercitar la sensibilidad y la empatía, modos de salirnos de nosotros/as mismos/as, de probar cómo sería ser otro/a.

K.L.: Eres una prolífica autora de poesía. Tu obra cuenta con nueve poemarios y varias antologías. ¿Hay cuestiones que solo pueden contarse a través de un poema?

C.M.: Creo que la poesía tiene una relación muy diferente con el lenguaje que la narrativa, o almenos, que la narrativa más lineal, más 


\section{Cristina León Sánchez}

ligada al despliegue del relato, la anécdota, la historia. Esa relación hace que sea un vehículo mucho más sensible, más preciso, a la hora de acercarse a experiencias que rozan lo intransmisible, lo inefable. Es un lenguaje mucho más depurado y despojado de su función práctica. Como dice el poeta Juanele Ortíz, en la poesía se quiebra la "función comunicacional del lenguaje". Deja de ser el lenguaje convencional, con el que todos/as creemos o "hacemos como que" nos entendemos, para transformarse en un modo diferente de acercarse a la experiencia, un modo mucho más elíptico y a la vez, aunque parezca paradójico, mucho más preciso.

\section{CRISTINA LEÓN SÁNCHEZ}

Universidad de Málaga 